\title{
Tüberküloz ve D Vitamini Arasındaki İlişkinin Değerlendirilmesi: Güncel Yaklaşımlar
}

\author{
Evaluation of the Association Between Tuberculosis and Vitamin D: \\ Current Approaches
}

\author{
Yücel Büyükdere, Aylin Ayaz \\ Hacettepe Üniversitesi, Sağllk Bilimleri Fakültesi, Beslenme ve Diyetetik Bölümü, Ankara, Türkiye \\ Yazışma Adresi / Correspondence: \\ Yücel Büyükdere \\ Hacettepe Üniversitesi, Sağlık Bilimleri Fakültesi, Beslenme ve Diyetetik Bölümü, Ankara, Türkiye \\ T: +90545 5407503 E-mail: Dyt.Yucel@gmail.com \\ Geliş Tarihi / Received : 04.04.2019 Kabul Tarihi / Accepted : 12.09.2019 \\ Orcid: \\ Yücel Büyükdere: https://orcid.org/0000-0003-2366-8735 \\ Aylin Ayaz: https://orcid.org/0000-0002-3543-7881 \\ ( Sakarya Tip Dergisi / Sakarya Med J 2019, 9(4):565-573) DOI: 10.31832/smj.549164
}

\footnotetext{
Öz

D vitamini güneşışılları aracilığıyla deride sentezlenen ve iskelet sistemi üzerinde olumlu etkileri bulunan steroid yapıda bir hormondur. D vitamininin bağışılık sistemi üzerindeki rolü, bağışıklık hücrelerinde D vitamini reseptörlerinin belirlenmesi ve makrofajlar, monositler ile aktive edilmiş T hücreleri gibi bağışılık hücrelerinde D vitamininin aktif formunun tanımlanmıs olmasıyla saptanmıștır. D vitamini, katelisidin ve defensin gibi antimikrobiyal peptidlerin salınımını artırarak, otofajiyi uyararak, Toll benzeri reseptörlerin sinyalizasyonunu değiştirerek, anti-inflamatuvar sitokinlerin salınımını artırarak ve dendritik hücrelerle T ve B lenfositlerin regülasyonunu sağlayarak doğal ve kazanılmıș bağışıklık sistemini modüle etmektedir. Mycobacterium tuberculosis etkeninin sebep olduğu sistemik bir bakteriyel enfeksiyon olan tüberküloza karşı, D vitamini bu mekanizmalarla olumlu etki göstermektedir. Bu derlemede D vitamininin tüberküloz hastalığı üzerindeki etkilerinin son güncel literatür verilerine göre incelenmesi amaçlanmıștır.

Anahtar Bağıșıllık; D vitamini; enfeksiyon; tüberküloz.

Kelimeler

Abstract

Vitamin D is a steroid hormone synthesized in the skin through sunlight and has positive effects on skeletal system. The role of vitamin D on the immune system have been demonstrated with the detection of vitamin $D$ receptors in immune cells and the discovery that vitamin $D$ can be converted into active form in immune cells such as macrophages, monocytes, activated $T$ cells. Vitamin D modulates the innate and adapted immune system by increasing the release of antimicrobial peptides such as cathelicidine and defensin, stimulating autophagy, modifying Toll-like receptor signaling, increasing the release of anti-inflammatory cytokines and regulating dendritic cells, T and B lymphocytes. Against tuberculosis, a systemic bacterial infection caused by Mycobacterium tuberculosis, vitamin D has a positive effect through these mechanisms. In this review, the effects of vitamin D on tuberculosis are aimed to be analyzed according to the latest current literature.

Keywords Immunity; vitamin D; infection; tuberculosis.
} 


\section{GIIRIŞ}

D vitamini (DV), yaşam için elzem, yağda çözünen bir maddedir. ${ }^{1}$ Bir dokuda üretilerek kan dolaşımına verilmesi, diğer dokular üzerinde etki göstermesi ve bu etkisinin feedback mekanizmalarla düzenlenmesi nedeniyle vitaminden çok steroid yapılı bir hormon olarak değerlendirilmektedir. ${ }^{2}$ DV'nin başlıca 2 formu bulunmaktadır. Bitkilerde ergesterolden sentezlenen formu ergokalsiferol (Vitamin D2) iken; diğer formu olan kolekalsiferol (Vitamin D3) deride 290-315 nanometre ( $\mathrm{nm}$ ) dalga boyunda ultraviyole B (UVB) 1şınlarına maruziyetle 7-dehidrokolesterolden (7-DHK) fotokimyasal ve termal olarak sentezlenmektedir. ${ }^{1-3}$ Deride previtamin D3 olarak sentezlenen DV, daha sonra enzimatik olmayan yolla hızlıca D3'e dönüşmektedir. ${ }^{1,4}$ İnsanlarda DV, başlıca derinin epidermal tabakasında sentezlenmesinin yanı sıra morina balığı karaciğeri yağı, süt ve süt ürünleri gibi sınırlı sayıdaki besinle vücuda alınabilmektedir. ${ }^{1,3-5}$ Hiçbir besin günlük ihtiyacı karşılayacak kadar DV içermediğinden güneş 1şı̆̆ı D vitamininin temel kaynağıdır. ${ }^{2}$ DV ilk kez raşitizm hastalığının tedavisinde tanımlanmıştır. ${ }^{3,5}$ Morina balığı karaciğeri yağ1 1827'de anti-raşitik aktivite gösteren çok iyi bir kaynak olarak keşfedilmiş; ancak bu etkiyi sağlayanın içeriğindeki aktif bileşen DV olduğu ise yıllar sonra keşfedilmiştir., DV; kemik, barsak, böbrek ve paratiroid bezi üzerinde gösterdiği fizyolojik etkilerle kalsiyum ve fosfor metabolizmasını düzenlemektedir. Biyolojik aktif formu olan 1,25-dihidroksi kolekalsiferol [1,25(OH)2D3 - kalsitriol], nükleer reseptör ailesinin bir üyesi olan $\mathrm{D}$ vitamini reseptörü (VDR) aracılığı ile birçok geni regüle ederek hücre farklılaşmasında, apoptozunda ve immün regülasyonda görev almaktadır. Ayrıca otoimmün ve alerjik rahatsızlıklarla enfeksiyon hastalıklarının önlenmesinde rolü bulunmaktadır. ${ }^{2}$ Bu derlemede, DV’nin önemli bir enfeksiyon olan tüberküloz (TB) hastalığı üzerindeki etkilerinin son güncel literatür verilerine göre incelenmesi amaçlanmıştır.

\section{Vitamini Metabolizması}

Deride sentez edilen veya besinlerle alınıp ince bağırsaklardan emilen D3, dolaşımda DV bağlayıcı proteine (DBP) bağlanıp karaciğere taşınmaktadır. Karaciğerde DV’ye afinitesi yüksek olan 25-hidroksilaz enzimi (CYP2R1) ile hidroksillenmektedir. Oluşan 25-hidroksi DV [25(OH) D] daha sonra böbreklerde 1- $\alpha$-hidroksilaz enzimi (CYP27B1) ile 2. kez hidroksillenerek DV'nin aktif formu olan 1,25(OH)2D3'ü oluşturur. ${ }^{4}$ Bağışıklık hücrelerinde de 1-a-hidroksilaz enzimi bulunmaktadır. ${ }^{1}$ Yarılanma-ömrü yaklaşık 2 hafta olan 25(OH)D insanlarda DV'nin dolaşımdaki temel formu olup plazma seviyeleri DV durumunu belirlemede rutin olarak kullanılmaktadır. ${ }^{1,4}$ Güncel literatürde serum DV seviyesinin $\geq 10 \mathrm{ng} / \mathrm{ml}$ ile $<20 \mathrm{ng} /$ $\mathrm{ml}$ arasında olması eksiklik olarak tanımlanmaktadır. ${ }^{6} \mathrm{DV}$ eksikliği küresel bir halk sağlı̆̆ı problemidir. ${ }^{7}$ Güncel verilere göre DV eksikliği dünyada \%92 oranla en fazla Kuzey Avrupa'da görülmektedir. Ülkemizin içinde bulunduğu Avrupada ise bu oran \%57-64 arasında değişmektedir. ${ }^{1,8}$

DV’nin aktif formu nükleer D vitamini reseptörüne bağlandıktan sonra oluşan kompleks, retinoik asit X reseptörüne (RXR) bağlanmakta ve bir heterodimerik kompleks oluşturmaktadır. Bu kompleks, insanlarda hedef genlerin promotör bölgelerinde yerleşik olan DV’ye yanıt oluşturan elemanlar (VDRE) olarak bilinen spesifik nükleotid sekanslarına bağlanır. Bağlandıktan sonra çeşitli transkripsiyon faktörleri bu komplekse bağlanmakta ve birçok genin aktivitesini up regüle veya down regüle etmektedir. ${ }^{4,8,9}$ Doğrudan veya dolaylı olarak 1,25(OH)2D3 tarafindan regüle edilen VDRE'ye sahip 200 ile 2000 gen olduğu tahmin edilmektedir. ${ }^{8}$ VDR'ler; pankreatik ß-hücreler, adipoz doku, tiroid bezi ile bağışıklık sistemi hücreleri dâhil olmak üzere farklı vücut yapılarında bulunmaktadır. ${ }^{2,4}$ DV'nin böbrek dışında sentez edildiği yönünde ilk bildiriler 1980'li yıllarda TB'li vakalara dayanmaktadır. Daha sonra makrofajların 25(OH)D'den aktif DV yapma yeteneklerinin olduğu bildirilmiştir. ${ }^{10}$ DV'nin iskelet sistemi dışındaki etkileri arasında bağışıklık sistemi ve enfeksiyon hastalıkları üzerindeki etkileri önemlidir. ${ }^{1}$

\section{Vitamini ve İmmün Sistem}

1,25(OH)2D3, bağışılklı sistemi homeostazisinin düzen- 
lenmesinde rol oynamaktadır. Monositler, makrofajlar, dendritik hücrelerin (DC) yanı sıra $\mathrm{T}$ ve $\mathrm{B}$ lenfositlerin immünomodülasyonunu sağlayarak doğal ve adaptif (kazanılmış) bağışıklığa yanıt oluşturduğu bildirilmiştir. ${ }^{4}$ DV; enfeksiyona karşı lokal doku cevabında etkili olup 1,25(OH)2D3/VDR kompleksi antimikrobiyal peptidlerin (AMP) üretiminin modülasyonunda etkilidir. ${ }^{11,12}$ AMP'ler patojenlere karşı geniş spektrumda aktivite gösteren doğal bağışıklık elemanlarıdır. ${ }^{11}$ DV’nin enfeksiyon hastalıklarına karşı anti-enfektif özellikleri olduğu gösterilmiştir. Patojenlere karşı konakçı bağışıklık yanıtı ve DV sinyalizasyonu arasında bir etkileşim olduğu belirtilmiştir. ${ }^{13} \mathrm{DV}$ eksikliği ve enfeksiyona duyarlılık arasındaki ilişki uzun yıllardır öne sürülmektedir. Randomize kontrollü klinik 13 çalışmanın dâhil edildiği bir sistematik derlemede, DV suplementasyonunun TB, influenza ve viral üst solunum yolu enfeksiyonları gibi enfektif hastalıklarda kullanılması hakkında daha düzgün tasarlanmış çalışmaların yapılması gerektiği vurgulanmıştır. ${ }^{14}$ DV eksikliğiyle ilişkili hastalıklar arasında enfeksiyonlar (özellikle solunum yolu), astım, hışırtılı akciğer hastalıkları ve TB önemli bir yer almaktadir. $^{10}$

DV’nin immün sistem fonksiyonları üzerindeki etkileri, 1980'lerde bağışıklık hücrelerinde VDR'lerin bulunmasıyla anlaşılmaya başlanmıştır. ${ }^{15,16} \mathrm{DV}$, monositlerin makrofajlara farklılaşmasında görev almakta, makrofajların kemotaktik ve fagositik kapasitesini artırmaktadır. ${ }^{4}$ VDR'ler, $\mathrm{T}$ ve $\mathrm{B}$ lenfositler, aktive edilmiş CD4+ ve CD8+ T hücreleri, nötrofil ve makrofajlar ile DC’ler gibi antijen sunan hücrelerde bulunmaktadır. ${ }^{3,417} \mathrm{Bu}$ hücreler vücudun patojenlere karşı doğal ve adaptif immün yanıtında önemlidir. ${ }^{17}$ Aktive edilmiş makrofajlar ve DC’ler CYP27B1 içermekte ve böbreklerden farklı olarak buradaki enzim Ca homeostatik sinyaliyle değil; başlıca interferon gama (IFN- $\gamma$ ) ve Toll-benzeri reseptör (TLR) modeli tanıyıcı reseptör agonistleri gibi immün elemanlarla regüle edilmektedir. ${ }^{3}$ DC'ler ayrica CYP2R1'i de eksprese etmektedir. Monositler/makrofajlarla CYP27B1 ekspresyonu IFN- $\gamma$, TLR4-ligand lipopeptidler, Mycobacterium tuberculosis (MTB)'in
19 kilodalton $(\mathrm{kDa})$ lipoproteini ve viral enfeksiyonlar gibi TLR2/1 kompleksini tetikleyen ligandlar tarafından güçlü bir şekilde up-regüle edilmektedir. ${ }^{4}$ TLR1 ve TLR2 uyar1mının yanı sıra TLR-4 ligand lipopolisakkaritleri (LPS) aktivasyonuyla da CYP27B1 aracılı VDR ile sağlanan doğal bağışılklı̆̆ın gözlendiği belirtilmiştir. ${ }^{18}$ Renal CYP27B1'in tersine makrofaj ve DC'lerde bu enzimin ekspresyonu 1,25(OH)2D3'ün kendi aktivitesi ile baskılanmamaktadır. ${ }^{4}$ 1,25(OH)2D3, doğal bağışıklık yanıtı olarak hücre farklılaşmasını etkilemektedir. ${ }^{1}$ Doğal bağışıklık invaziv patojenlere karşılık veren ilk bağışıklık yanıtı iken; kazanılmış bağışıklıkta, makrofajlar ve DC’ler gibi hücreler tarafından sunulan antijenlere karşı $\mathrm{T}$ ve B lenfositler sitokin ve immünoglobülinler (Ig) üreterek işlev yapmaktadır. ${ }^{10}$ Doğal bağışıklıkta, doğrudan anti-fagositik aktivite gösteren nötrofiller, monositler ve epitel hücreleri üzerindeki TLR'ler gibi patojen tanıyıcı reseptörlere (PRR) bağlanan patojen ilişkili moleküler paternler ile patojenler tanımlanırlar., ${ }^{4,17}$ Böylece tehlikeli mikrobiyal istilacılara karşı ilk aşamada savunma sağlanmaktadır. DV, TLR2 ve TLR4 inhibisyonu ile patojenlerle savaşta bağışıklık yanıtı oluşturmaktadır.,13 LPS’ler ve bakteriyel lipoproteinler dâhil olmak üzere mikrobiyal ligandlar, memeli TLR'lerini aktive edip adaptif yanıtı düzenleyen genlerin transkripsiyonunu kolaylaştırmaktadır. ${ }^{19}$ TLR'lerin patojen mikroorganizma tanıma özelliği bulunmakta ve patojen tarafından bu reseptörün uyarılması konakçıda doğal immüniteyi uyarmaktadır. Böylece AMP'ler uyarılmakta ve bu da mikroorganizmaların ölümü ile sonuçlanmaktadır. ${ }^{10}$

AMP'ler, patojenlere karşı doğal bağışıklık yanıtlarının öncüleri olup, çoğunluğu doğrudan patojen membranların bütünlügünü bozarak hareket etmektedir. Katelisidin (CAMP, hCAP18 veya LL-37) ve $ß$-defensin-2 (DEFB2) önemli AMP’lerdir.3 Katelisidin AMP ekspresyonu epitel hücreler, makrofajlar/monositler ve nötrofillerde 1,25(OH)2D3 ile kuvvetli şekilde uyarılırken DEFB2 ekspresyonu ise daha hafif şekilde uyarılmaktadır. CAMP ve DEFB2; VDR hedef genleridir. ${ }^{5}$ AMP ekspresyonunda türler arası farklılıklar bulunmaktadır. Kemirgenlerde kateli- 
sidin ve ß-defensinleri kodlayan genler VDR aracılığıyla kontrol edilmemekte olup farelerde bu genler DV ile indüklenmemektedir. ${ }^{3,11,20}$ Fare makrofajlarında antimikrobiyal aktivitenin indüklenmesi, indüklenebilir nitrik oksit sentaz aktivitesine bağlıdır. Ancak insan hücrelerinde böyle bir durum söz konusu değildir. ${ }^{3}$

İnsanlarda tek bir gen, insan katyonik antimikrobiyal proteini 18 (hCAP18) adındaki öncü proteinini kodlamaktadır. Bu proteinin ayrılmasıyla da LL-37, C-terminal aminoasit parçası katyonik 37 proteini oluşmaktadır., ${ }^{5,9,11}$ LL-37, VDR içeren alanlara sahiptir. 1,25(OH)2D3, insanlarda nötrofillerde LL-37 düzeylerini artırmaktadır. DV ayrıca konakçı savunmasını, deride LL-37 sentezini ve dolaşımdaki fagositik hücrelerin sentezini uyararak artırmaktadır. ${ }^{20}$ İnsanlarda katelisidin, promotör bölgelerinde çok sayıda aktif VDRE bulundurmaktadır. ${ }^{9}$ LL37'nin sahip olduğu katyonik yapı, mikroorganizmaların membran bütünlüğünün bozulmasına yol açtığı antimikrobiyal aktivitesinde önemlidir. ${ }^{5}$ Bakteri enfeksiyonunda otofajinin D vitaminiyle indüklenmesinde katelisidin önemli role sahiptir. Otofaji antimikrobiyal savunmaya katkı sağlayan katabolik bir yoldur. VDR sinyal aktivasyonunun otofajiyi etkilediği belirtilmiştir. D3 ve otofaji, doğal bağışıklık ve enfeksiyonlarla ilişkili bulunmuştur. D3 sinyalizasyonunun katelisidin aracılığıla otofajiyi inhibe ederek bakterileri öldürebileceği ileri sürülmüştür. ${ }^{9}$ İnsan monosit ve epitel hücrelerinde 1,25(OH)2D3'ün CAMP ile DEFB2'nin sinerjistik olarak indüksiyonuna neden olduğu gösterilmiştir. ${ }^{21} \mathrm{NF}-\kappa \mathrm{B}$, enfeksiyon sırasında inflamatuvar proteinlerin transkripsiyonu ile ilişkili bir protein kompleksidir. $^{22}$

Kazanılmış bağışıklıkta DV; B ve T hücrelerinin proliferasyonunu etkilemekte ve Ig üretimini modüle etmektedir. ${ }^{17}$ Antijenle uyarılan $\mathrm{T}$ hücreleri sitokin üretme durumuna göre iki farklı tip T hücreye ayrılmaktadır. Bunlar T yardimc1-1 (Th1) ve T yardımc1-2 (Th2) hücreleridir. Th1 hücreleri; proinflamatuvar sitokinler olan IFN- $\gamma$, interlökin-2 (IL-2) ve tümör nekroz faktör-alfa (TNF- $\alpha$ ) üret- mekte ve kuvvetli hücresel immün cevaptan sorumludur. Th2 hücreleri ise anti-inflamatuvar sitokinler olan IL-4, IL-5 ve IL-10 üretmekte ve antikor merkezli immün cevaptan sorumludur. Bu iki hücre tipi arasındaki dengenin bozulması immün yanıtın hangi yönde çalışacağını göstermektedir. ${ }^{10}$ Aktif DV’nin, DC hücre belirteci olan büyük doku uygunluk kompleksi sınıf II ile komplekslenmiş antijenin ve ortak uyarıcı moleküllerin (CD40, CD83 ve CD86) yüzey ekspresyonunu ve Th1 profilindeki hücreleri inhibe ederek, T hücre polarizasyonunu Th1 ile Th17'den Th2 aracılı fenotipe dönüştürerek adaptif immünitede rol

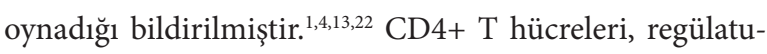
var (Treg) ve baskılayıcı T hücrelerine dönüşebilir. Aktif DV; CD4/CD25 ile Treg'leri pozitif yönde etkilemektedir. DV eksikliği durumunda ise Treg sayı ve aktivitesi bozulup daha güçlü bir Th1 cevabı oluşur ve immün yanıt bozulup enfeksiyonlara eğilim artar. Aktif DV, dolayısıyla Th2 ve Treg hücrelerinin üretiminin artması yoluyla da kazanılmış bağışıklığa katkı sağlamaktadır. ${ }^{10}$

DV; B-hücrelerinin üretimini, B hücrelerinin plazma hücrelerine farklılaşmasını ve B hücreleri tarafından IgG ve IgM üretimini inhibe ederek de kazanılmış bağışıklığa katkı sağlamaktadır.,23 DV, IL-6 ve IL-23’ü inhibe ederek Th17 aracilı immün yanıtı da azaltmaktadır. ${ }^{22}$ Th1, Th2, Treg ve Th17; CD4+ T hücrelerinin alt gruplarından olup Th17 ve Treg; Th1 ve Th2'den farklı alt gruplardır. Treg kendisine özgü spesifik transkripsiyon faktörü olan Foxp3'ü içermektedir. ${ }^{23} 1,25(\mathrm{OH}) 2 \mathrm{D} 3$, DC'lerin modülasyonu yoluyla ve doğrudan T hücrelerini hedefleyerek Treg hücre gelişimini desteklemektedir.4 Ayrıca, IL-10 üretimini kolaylaştırarak Treg hücrelerinin üretimini teşvik etmektedir. ${ }^{4,22} \mathrm{DV}$, düzenlenmiş mannoz reseptör ekspresyonunu artırdığ 1 için DC bağlanması ve yabancı antijenlerin yakalanmasında önemli bir rol oynayabilir. ${ }^{4}$

\section{Vitamini ve Tüberküloz}

TB; MTB’nin neden olduğu çoklu, sistemik bir bakteriyel enfeksiyondur. ${ }^{1}$ MTB, konakçı immünitesini bozarak latent bir durumda tutulmakta ya da oluşan enfeksiyon, 
en yaygın olarak akciğerde ortaya çıkan aktif TB’ye neden olarak ilerlemektedir. ${ }^{11}$ Dünya Sağlık Örgütü’nün (DSÖ) 2018'de yayımlanan son TB raporuna göre, TB’nin dünyada en çok 10 ölüm nedeninden biri olduğu bildirilmiştir. Küresel olarak (2017 yılı) 10 milyon insanda TB hastalığ geliştiği tahmin edilmektedir. Dünya nüfusunun \%23’ü olan yaklaşık 1,7 milyar insanın ise latent TB enfeksiyonuna sahip olduğu tahmin edilmekte olup bu nedenle yaşamları boyunca aktif TB hastalığına yakalanma riski bulunmaktadır. TB'den ölen insan sayısının 2000 yılına kıyasla 2017 yılında \%23’ten \%16’ya düştügü belirlenmiştir. ${ }^{24}$

DV eksikliği; TB enfeksiyonu için bir risk faktörüdür.1,11 DV yetersizliğiyle enfeksiyon hastalıkları arasındaki ilişki, 19. yüzyılda güneş 1şı̆̆ı radyasyonunun TB'li bireyler için yararlı olduğunun anlaşılmasına dayanmaktadır. ${ }^{3}$ Yüksek yoğunluklu UV ışınlarına maruziyetin, TB’nin deride gözlenen formu olan lupus vulgaris hastalarını tedavi edici olarak kullanıldığının gösterilmesiyle Nobel ödülü kazanılmıştır. ${ }^{13}$ TB vakalarında balık karaciğeri tükettirilerek tedavi uygulanması ise 19. yüzyıla dayanmakta olup o dönemlerde pulmoner hasarın tedavisinde herhangi bir tedavi edici ajandan daha etkili olduğu görüşü Williams tarafından ileri sürülmüştür. Ancak balık karaciğerinin içerisindeki hangi etmenin buna neden olduğu hakkında bir fikir sunulmamıştır. ${ }^{25}$ DV’nin morina balığ karaciğeri yağından izolasyonu ile birlikte TB tedavisi ve önlenmesinde kullanımı, 1950'lerde kimyasal ajanlarla anti-enfektif tedavisi bulunana kadar devam etmiştir. ${ }^{14,26}$ Bir meta-analizinde (38 çalışma), TB'li vakalarda DV düzeyinin anlamlı düzeyde düşük olduğu ve DV eksikliğinin TB riski ile ilişkili olduğu belirlenmiştir. DV eksikliğinin TB için sonuçtan daha çok bir risk faktörü olduğu ve DV takviyesinin TB önleme ve tedavisine faydalı olup/olmadığını belirlemek için daha fazla çalışmaya ihtiyaç olduğu gösterilmiştir. ${ }^{27}$

D vitamininin TB’ye karşı koruma mekanizmaları tam olarak anlaşılmış değildir. ${ }^{28}$ İlk olarak 1980’lerde 1,25(OH)2D3'ün MTB ile enfekte edilmiş insan monosit ve makrofaj hücrelerinde in vitro olarak antimikrobiyal aktiviteyi uyardığg ve TB etkeninden koruma sağladığ1 gösterilmiştir. ${ }^{29,30}$ Antijene spesifik CD4+ T hücrelerinin aracılık ettiği adaptif immün yanıtın, MTB’ye karşı başlıca immünolojik savunma mekanizması olduğuna inanılmaktadır. Th17 ve Treg arasında doğru dengeyi korumanın aktif TB immünopatogenezi için kritik olabildiği ve yapılan bir çalışmada aktif TB'li hastalarda Treg/Th17 dengesinin değiştiği, periferik tek çekirdekli kan hücrelerinde (PBMC) hem Th17 hem de Treg yüzdelerinde anlamlı derecede artış olduğu gösterilmiştir. ${ }^{23}$ D3'ün MTB'ye karşı antagonist aktivitesinde otofaji ve AMP'ler aracılı etkisi önemlidir. ${ }^{9}$ MTB lipopeptidleri ile enfekte edilen ve $1,25(\mathrm{OH}) 2 \mathrm{D} 3$ ile müdahale edilen insan monositlerinin ve makrofajlarının memelilerde bulunan TLR homologları olan TLR2 ve TLR1 ligandları (TLR 2/1L) aracılı aktivasyonunun CYP27B1, VDR ve VDR-hedefli diğer genlerin up-regülasyonu ile sonuçlandığı ve CAMP indüksiyonu ile MTB’nin ölümüne neden olduğu gösterilmiștir. ${ }^{31}$

Fare makrofajlarında TLR2'nin bakteriyel lipoproteinler gibi mikrobiyal ligandlarla aktivasyonunun, nitrik okside bağımlı bir mekanizma ile hücre içi MTB’yi öldürdüğü belirtilirken; insan monosit ve alveolar makrofajlarında bu yolun nitrik oksitten bağımsız olduğu; antimikrobiyal aktivitenin ve konakçı savunmasının TLR2 sinyalizasyonuna bağlı olduğu gösterilmiştir. ${ }^{19}$ Yapılan bir çalışmada hem IL-4'ün hem de IL-15'in makrofaj farklılaşmasına neden olduğu; ancak sadece IL-15'in tek başına CYP27B1'i indükleyebildiği ve 25(OH)D’yi 1,25(OH)2D3’e dönüştürerek MTB’ye karşı VDR aktivasyonunu ve katelisidin indüksiyonunu sağlayabildiği gösterilmiştir. ${ }^{32}$ Ayrıca yeni bir mekanizma olarak 1,25(OH)2D3'ün makrofajlarda miRNA ve miR-155'i down-regüle eden sitokin sinyalizasyonu-1 baskılayıcıyı uyararak TLR sinyalizasyonunu düzenleyebildiği bildirilmiştir. ${ }^{33}$ MTB’nin; otofajide olduğu gibi TLR2 sinyalizasyonu aracılığıyla DC’lerde katelisidin ekspresyonunu inhibe ettiği gösterilmiştir. ${ }^{34} 1,25(\mathrm{OH}) 2 \mathrm{D} 3$ 'ün MTB ile enfekte olmuş makrofajlarda TLR2, TLR4, dektin-1 ve mannoz reseptörü gibi PRR'leri down regüle ede- 
rek de etki gösterdiği belirtilmiştir. Ayrıca MTB ile uyarılan matriks metalloproteinazlarının ekspresyonlarını da down regüle ederek bağışıklık hücrelerinde TB’ye karşı koruma sağladığ ${ }_{1}$ bildirilmiştir. ${ }^{11}$

Ekzojen olarak verilen 1,25(OH)2D3'ün fosfotidil inositol 3-kinaz (PI-3K) aracılığıla VDR membran reseptörüne ligand bağlanması yaparak fagolizozomal füzyonü artırdığı; bunun dışında nitrik oksit sentaz (NOS2A) üretimini uyararak doğal bağışıklıkta konakçı bağışıklık yanıtını modüle edici özellik gösterdiği belirtilmiştir. ${ }^{28} \mathrm{PI}-3 \mathrm{~K}$ çok işlevli bir sinyal molekülü olup, insan makrofaj hücre hatları ve periferik kan monositlerinde D3 vitamini ile indüklenen hücre farklılaşması için gereklidir. VDR-PI3K kompleksi D3 ile aktive edilen yeni bir sinyalizasyon yolağıdır. ${ }^{35}$ MTB ile enfekte edilmiş insan PBMC kültürlerinde 1,25(OH)2D3'ün doza bağımlı olarak mikobakteri üremesini başlıca VDR aracılı azalttığı; ayrıca katelisidin hCAP18 gen ekspresyonunu güçlü şekilde up-regüle ederek antimikrobiyal etki gösterdiği belirlenmiştir. hCAP18 geninin yanı sıra 1,25(OH)2D3'ün NOS2A genini de kısmen up-regüle ederek reaktif nitrojen ara ürünleri oluşumunu kısmen azaltarak da antimikrobiyal etkiye katkıda bulunduğu gösterilmiştir.28 Bunun dışında monositlerde MTB'nin TLR1-TLR2 heterodimerlerine bağlanmasıyla IL-1'i aktive edip NF-кB'yi indüklediği gösterilmiştir. MTB'nin fagositozunun da bir hücre içi PRR olan NOD2'yi aktive ederek NF- $\kappa B$ aktivitesini artırdığ 1 belirlenmiştir. Sonuçta NF- $\kappa$ B’nin katelisidin ile $ß$-defen$\sin 4 \mathrm{~A}$ ekspresyonunu ve otofajiyi uyararak antibakteriyel aktiviteyi sağladığı ortaya konmuştur. ${ }^{1}$ Yapılan bir çalışmada, düşük serum DV düzeylerine sahip aktif TB hastalarının, mikobakteriyel antijenlerin biriktiği pulmoner lezyonlarda LL-37 ekspresyonunu anlamlı ölçüde azalttığı ilk kez gösterilmiştir. ${ }^{36}$ Ayrıca granülomatöz TB lezyonlarında, FoxP3+ Treg hücrelerinin ve IL-21 up regülasyonu ile ilişkili IgG salgılayan CD20+ B hücrelerinin artışı gözlenmiştir. ${ }^{36}$ DV'nin bu yolakları inhibe ederek immün yanıtı artırdığı bilinmektedir., ${ }^{3,13}$ Tablo 1'e bakıldığında; DV suplementasyonunun TB ve DV düzeyleri üzerinde genel olarak olumlu etkileri olduğu görülse de; uygulanan DV suplementasyonlarının dozu ve uygulama sürelerinde bir konsensus bulunmamaktadır. ${ }^{37-46}$

\section{Sonuç ve Öneriler}

D vitamini, MTB etkenine karşı immünomodülatör olarak görev yapan bir besin ögesidir. Doğal ve bağışıklık sistemi üzerinde çeşitli mekanizmalar üzerinden gösterdiği olumlu etkilerle ciddi bir sistemik bakteriyel rahatsızlık olan TB'ye karşı koruma sağladığı, TB semptomlarını hafiflettiği farklı çalışmalarla gösterilmiştir. Ancak yapılan çalışmalarda kullanılan DV suplementasyonu düzeyi, süreleri ve çalışma tasarımları arasında bir fikir birliği bulunmamaktadır. DV’nin bağışıklığı destekleyici etkileri birçok açıdan ele alınsa da henüz ortaya konmamış ve açık olmayan daha fazla mekanizma olabileceği belirtilmiştir. Bundan dolayı TB etkenine karşın DV'nin etkilerini inceleyen daha kapsamlı çalışmaların yapılmasına ihtiyaç duyulmaktadır.

\section{Çıkar ilişkisi/Conflict of interest}

Yazarlar ya da yazı ile ilgili bildirilen herhangi bir çıkar çatışması yoktur. 


\begin{tabular}{|c|c|c|c|c|c|c|c|c|c|}
\hline & & 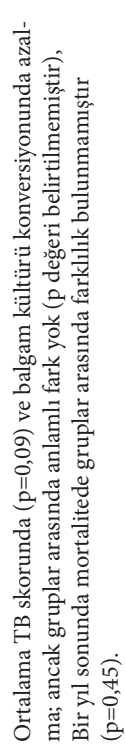 & 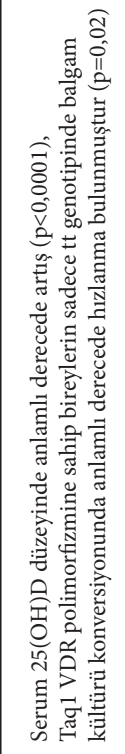 & 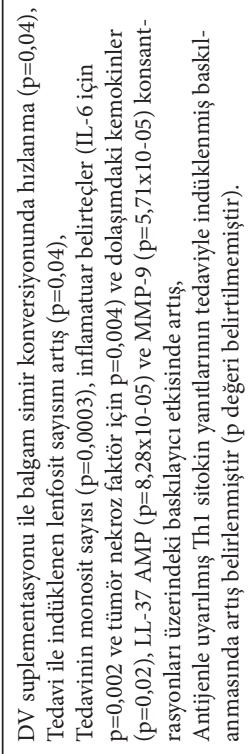 & 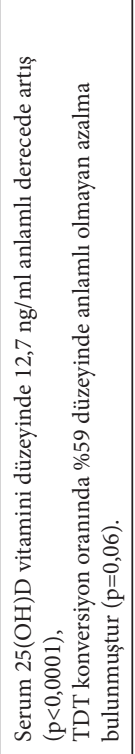 & 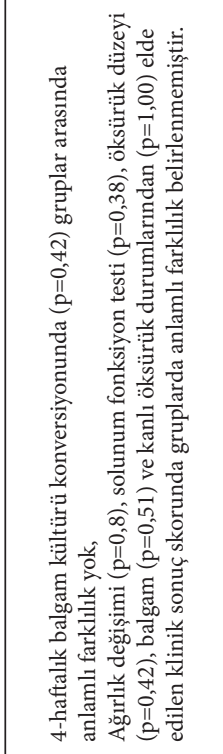 & 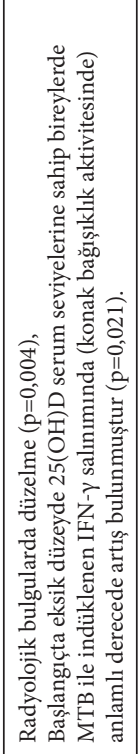 & 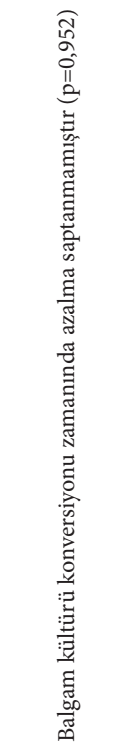 & 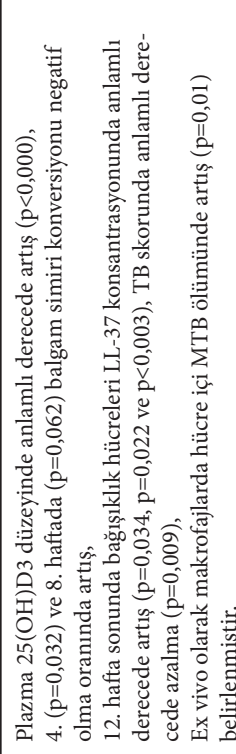 \\
\hline 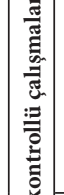 & & 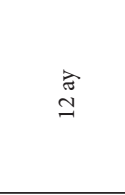 & $\begin{array}{l}\text { 或 } \\
\text { in }\end{array}$ & 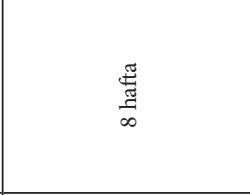 & 死 & 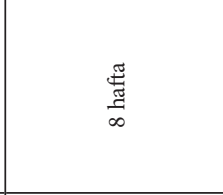 & $\begin{array}{l}\text { 莺 } \\
\text { In }\end{array}$ & $\begin{array}{l}\frac{\pi}{\pi} \\
\frac{\pi}{\infty}\end{array}$ & 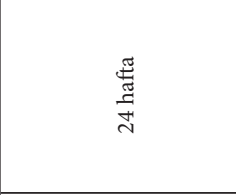 \\
\hline 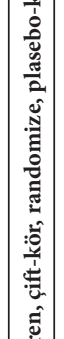 & 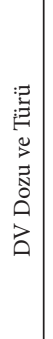 & 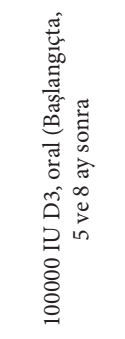 & 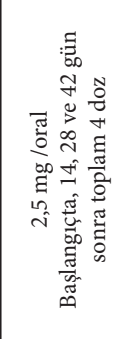 & 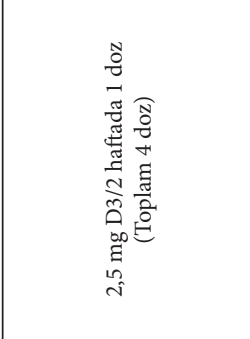 & 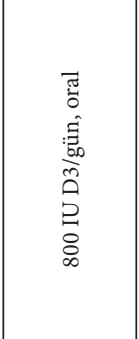 & 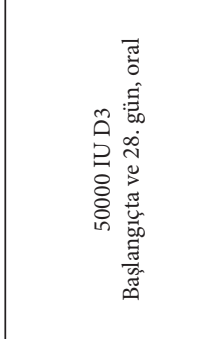 & 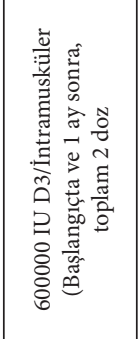 & 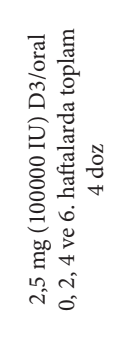 & 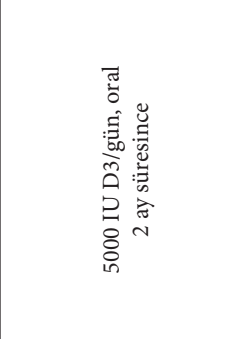 \\
\hline 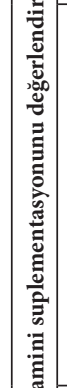 & 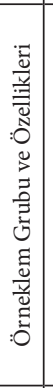 & 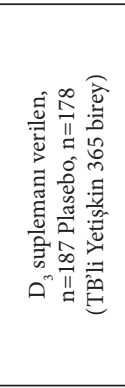 & 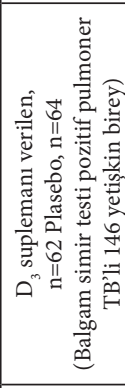 & 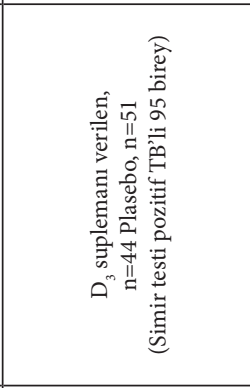 & 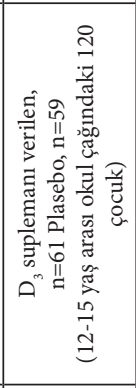 & 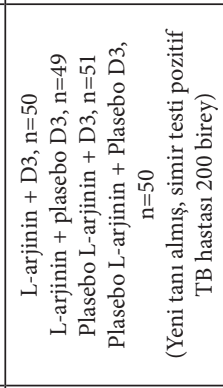 & 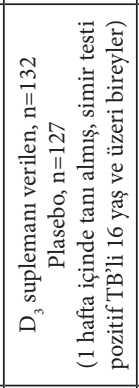 & 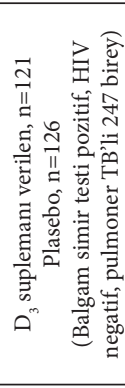 & 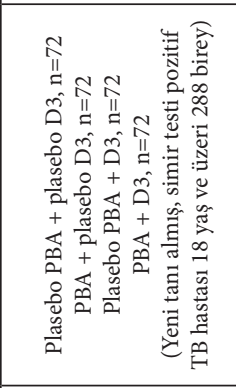 \\
\hline 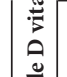 & $\vec{\nabla}$ & ఫ्रे & $\overline{\vec{i}}$ & ב̃ & تี & 旁 & $\stackrel{m}{\vec{i}}$ & $\stackrel{n}{\vec{n}}$ & $\stackrel{n}{n}$ \\
\hline 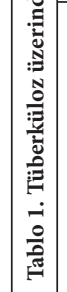 & 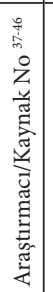 & 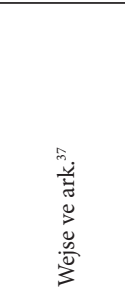 & 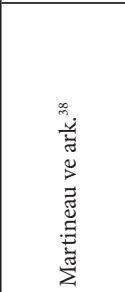 & 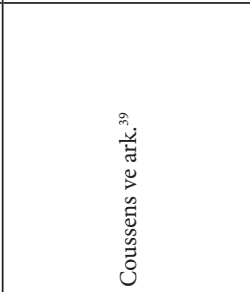 & 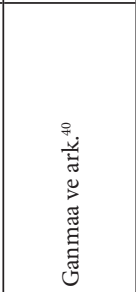 & 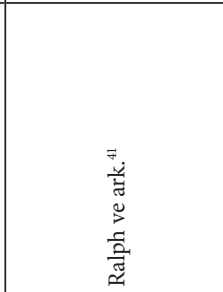 & 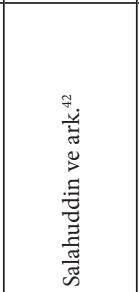 & 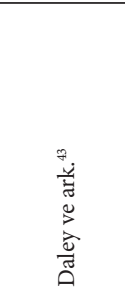 & 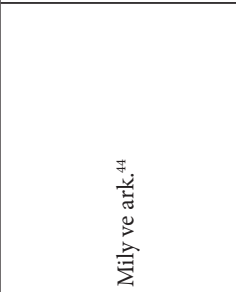 \\
\hline
\end{tabular}




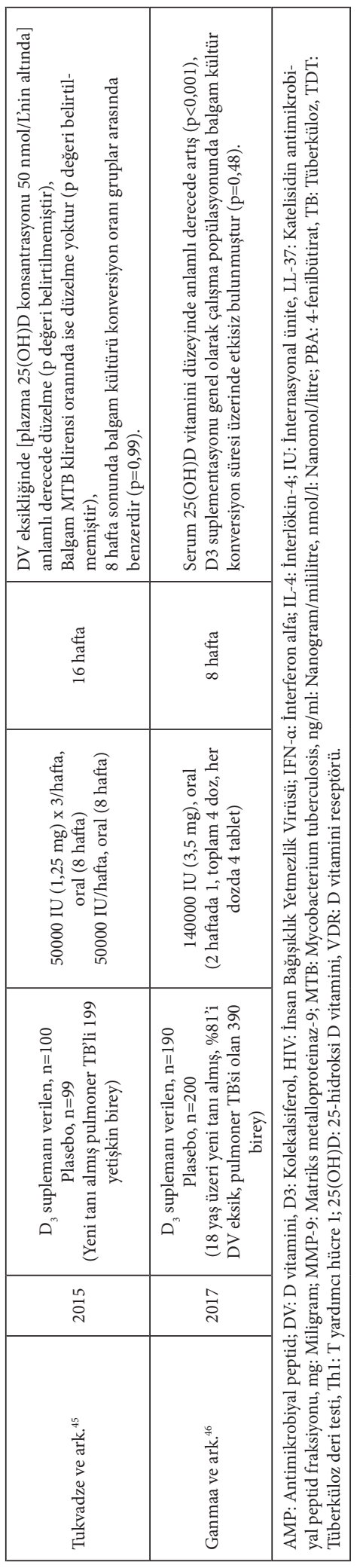




\section{Sakarya Tip Dergisi 2019;9(4):565-573}

\section{Kaynaklar}

1. Gois P, Ferreira D, Olenski S, Seguro A. Vitamin D and Infectious Diseases: Simple Bystander or Contributing Factor? Nutrients 2017;9(7):651

2. Tellioğlu A, Bașaran S. Güncel Bilgiler Ișı̆̆ı̆ında Vitamin D. ARȘì 2013;22(2):259-71.

3. White JH. Vitamin D Signaling, Infectious Diseases, and Regulation of Innate Immunity. Infect Immun 2008; 76(9):3837-43.

4. Baeke F, Takiishi T, Korf H, Gysemans C, Mathieu C. Vitamin D: modulator of the immune system. Curr Opin Pharmacol 2010;10(4):482-96.

5. White JH. Vitamin D as an Inducer of Cathelicidin Antimicrobial Peptide Expression: Past, Present and Future. J Steroid Biochem Mol Biol 2010;121(1-2):234-8.

6. Souto Filho JTD, de Andrade AS, Ribeiro FM, Alves PAS, Simonini VRF. Impact of vitamin D deficiency on increased blood eosinophil counts. Hematol Oncol Stem Cell Ther 2018;11(1):25-9.

7. Pludowski P, Holick MF, Grant WB, Konstantynowicz J, Mascarenhas MR, Haq A, et al. Vitamin D supplementation guidelines. J Steroid Biochem Mol Biol 2018;175:125-35.

8. Hossein-nezhad A, Holick MF. Vitamin D for Health: A Global Perspective. Mayo Clin Proc 2013;88(7):720-55.

9. Wu S, Sun J. Vitamin D, Vitamin D Receptor, and Macroautophagy in Inflammation and Infection. Discov Med 2011;11(59):325.

10. Özkan B, Döneray H. D vitamininin iskelet sistemi dışı etkileri. Cocuk Sag Hast Derg 2011;54(2):99-119.

11. Brighenti S, Bergman P, Martineau AR. Vitamin D and tuberculosis: where next? J Intern Med 2018;284(2):145-62

12. Kempker JA, Tangpricha V, Ziegler TR, Martin GS. Vitamin D in sepsis: from basic science to clinical impact. Crit Care 2012;16(4):316.

13. Korf H, Decallonne B, Mathieu C. Vitamin D for infections. Curr Opin Endocrinol Diabetes Obes 2014;21(6):431-6.

14. Yamshchikov A, Desai N, Blumberg H, Ziegler T, Tangpricha V. Vitamin D for Treatment and Prevention of Infectious Diseases: A Systematic Review of Randomized Controlled Trials. Endocr Pract 2009;15(5):438-49.

15. Bhalla AK, Amento EP, Clemens TL, Holick MF, Krane SM. Specific high-affinity receptors for 1, 25-dihydroxyvitamin D3 in human peripheral blood mononuclear cells: presence in monocytes and induction in T lymphocytes following activation. J Clin Endocrinol Metab 1983;57(6):1308-10.

16. Provvedini DM, Tsoukas CD, Deftos LJ, Manolagas SC. 1,25-dihydroxyvitamin D3 receptors in human leukocytes. Science 1983;221(4616):1181-3.

17. Kempker JA, Han JE, Tangpricha V, Ziegler TR, Martin GS. Vitamin D and sepsis: An emerging relationship. Dermatoendocrinol 2014;4(2):101-8.

18. Adams JS, Ren S, Liu PT, Chun RF, Lagishetty V, Gombart AF, et al. Vitamin D-Directed Rheostatic Regulation of Monocyte Antibacterial Responses. J Immunol 2009;182(7):428995.

19. Thoma-Uszynski S, Stenger S, Takeuchi O, Ochoa MT, Engele M, Sieling PA, et al. Induction of direct antimicrobial activity through mammalian toll-like receptors. Science 2001;291(5508):1544-7.

20. Zasloff M. Fighting Infections With Vitamin D. Nat Med 2006;12(4):388.

21. Wang T-T, Dabbas B, Laperriere D, Bitton AJ, Soualhine H, Tavera-Mendoza LE, et al. Direct and Indirect Induction by 1,25-Dihydroxyvitamin D3of the NOD2/CARD15-Defensin B2 Innate Immune Pathway Defective in Crohn Disease. J Biol Chem 2010;285(4):2227-31. 22. Sundaram ME, Coleman LA. Vitamin D and Influenza. Adv Nutr 2012;3(4):517-25.

23. Luo J, Zhang M, Yan B, Zhang K, Chen M, Deng S. Imbalance of Th17 and Treg in peripheral blood mononuclear cells of active tuberculosis patients. Braz J Infect Dis 2017;21(2):155-61. 24. Organization WH. WHO Global Tuberculosis Report 2018 Executive Summary. 2018.

25. Williams CJB. On the Use and Administration of Cod-Liver Oil in Pulmonary Consumption. Lond J Med 1849;1(1 (Jan., 1849)):1-18.

26. Martineau AR, Honecker FU, Wilkinson RJ, Griffiths CJ. Vitamin D in the treatment of pulmonary tuberculosis. J Steroid Biochem Mol Biol 2007;103(3-5):793-8.

27. Huang SJ, Wang X, Liu ZD, Cao WL, Han Y, Ma AG, et al. Vitamin D deficiency and the risk of tuberculosis: a meta-analysis. Drug Des Devel Ther 2016;Volume11:91-102.

28. Martineau AR, Wilkinson KA, Newton SM, Floto RA, Norman AW, Skolimowska K, et al. IFN- $\gamma$ - and TNF-Independent Vitamin D-Inducible Human Suppression of Mycobacteria: The Role of Cathelicidin LL-37. J Immunol 2007;178(11):7190-8.
29. Rook GA, Steele J, Fraher L, Barker S, Karmali R, O'riordan J, et al. Vitamin D3, gamma interferon, and control of proliferation of Mycobacterium tuberculosis by human monocytes. Immunology 1986;57(1):159.

30. Crowle AJ, Ross EJ, May MH. Inhibition by 1, $25(\mathrm{OH})$ 2-vitamin D3 of the multiplication of virulent tubercle bacilli in cultured human macrophages. Infect Immun 1987;55(12):294550.

31. Liu PT, Stenger S, Li H, Wenzel L, Tan BH, Krutzik SR, et al. Toll-like receptor triggering of a vitamin Dmediated human antimicrobial response. Science 2006;311(5768):1770-3.

32. Krutzik SR, Hewison M, Liu PT, Robles JA, Stenger S, Adams JS, et al. IL-15 Links TLR2/1-Induced Macrophage Differentiation to the Vitamin D-Dependent Antimicrobial Pathway. J Immunol 2008; 181(10):7115-20.

33. Chen Y, Liu W, Sun T, Huang Y, Wang Y, Deb DK, et al. 1,25-Dihydroxyvitamin D Promotes Negative Feedback Regulation of TLR Signaling via Targeting MicroRNA-155-SOCS1 in Macrophages. J Immunol 2013;190(7):3687-95.

34. Rode AKO, Kongsbak M, Hansen MM, Lopez DV, Levring TB, Woetmann A, et al. Vitamin D Counteracts Mycobacterium tuberculosis-Induced Cathelicidin Downregulation in Dendritic Cells and Allows Th1 Differentiation and IFN $\gamma$ Secretion. Front Immunol 2017;8. 35. Sly LM, Lopez M, Nauseef WM, Reiner NE. 1 $\alpha$,25-Dihydroxyvitamin D3-induced Monocyte Antimycobacterial Activity Is Regulated by Phosphatidylinositol 3-Kinase and Mediated by the NADPH-dependent Phagocyte Oxidase. J Biol Chem 2001;276(38):35482-93.

36. Rahman S, Rehn A, Rahman J, Andersson J, Svensson M, Brighenti S. Pulmonary tuberculosis patients with a vitamin $D$ deficiency demonstrate low local expression of the antimicrobial peptide LL-37 but enhanced FoxP3+ regulatory T cells and IgG-secreting cells. Clin Immunol 2015;156(2):85-97.

37. Wejse C, Gomes VF, Rabna P, Gustafson P, Aaby P, Lisse IM, et al. Vitamin D as Supplementary Treatment for Tuberculosis. Am J Respir Crit Care Med 2009;179(9):843-50.

38. Martineau AR, Timms PM, Bothamley GH, Hanifa Y, Islam K, Claxton AP, et al. High-dose vitamin D3 during intensive-phase antimicrobial treatment of pulmonary tuberculosis: a double-blind randomised controlled trial. Lancet 2011;377(9761):242-50.

39. Coussens AK, Wilkinson RJ, Hanifa Y, Nikolayevskyy V, Elkington PT, Islam K, et al. Vita min $D$ accelerates resolution of inflammatory responses during tuberculosis treatment. Proc Natl Acad Sci 2012;109(38):15449-54.

40. Ganmaa D, Giovannucci E, Bloom BR, Fawzi W, Burr W, Batbaatar D, et al. Vitamin $D$, tuberculin skin test conversion, and latent tuberculosis in Mongolian school-age children: a randomized, double-blind, placebo-controlled feasibility trial. Am J Clin Nutr 2012;96(2):391-6.

41. Ralph AP, Waramori G, Pontororing GJ, Kenangalem E, Wiguna A, Tjitra E, et al. L-arginine and Vitamin D Adjunctive Therapies in Pulmonary Tuberculosis: A Randomised, Double-Blind, Placebo-Controlled Trial. PLoS One 2013;8(8):e70032.

42. Salahuddin N, Ali F, Hasan Z, Rao N, Aqeel M, Mahmood F. Vitamin D accelerates clinical recovery from tuberculosis: results of the SUCCINCT Study [Supplementary Cholecalciferol in recovery from tuberculosis]. A randomized, placebo-controlled, clinical trial of vitamin D supplementation in patients with pulmonary tuberculosis'. BMC Infect Dis 2013;13(1):22.

43. Daley P, Jagannathan V, John KR, Sarojini J, Latha A, Vieth R, et al. Adjunctive vitamin D for treatment of active tuberculosis in India: a randomised, double-blind, placebo-controlled trial. Lancet Infect Dis 2015;15(5):528-34.

44. Mily A, Rekha RS, Kamal SMM, Arifuzzaman ASM, Rahim Z, Khan L, et al. Significant Effects of Oral Phenylbutyrate and Vitamin D3 Adjunctive Therapy in Pulmonary Tuberculosis: A Randomized Controlled Trial. PLoS One 2015;10(9):e0138340.

45. Tukvadze N, Sanikidze E, Kipiani M, Hebbar G, Easley K, Shenvi N, et al. High-dose vitamin D3 in adults with pulmonary tuberculosis: a double-blind randomized controlled trial. Am J Clin Nutr 2015;102(5):1059-69.

46. Ganmaa D, Munkhzul B, Fawzi W, Spiegelman D, Willett W, Bayasgalan P, et al. High-Dose Vitamin D3 during Tuberculosis Treatment in Mongolia. A Randomized Controlled Trial. Am J Respir Crit Care Med 2017;196(5):628-37. 